\title{
The Mobile Fauna - Especially Gammaridea - of Sargassum cymosum*
}

\author{
A. S. Tararam and Y. Wakabara \\ Instituto Oceanográfico, Universidade de São Paulo, Cidade Universitária, Butantã - 05508, SP, Brazil
}

\begin{abstract}
A comparative study was made on the composition of the vagile fauna inhabiting the alga Sargassum cymosum collected at 2 sites, differing in wave action, on the northern coast of Sào Paulo State, Brazil $\left(23^{\circ} 30^{\prime} \mathrm{S}\right.$ and $\left.45^{\circ} 06^{\prime} \mathrm{W}\right)$. A total of 122.886 specimens were collected at 2 stations, belonging to 23 taxonomic groups. Gammaridea comprised the dominant group at both sites: 15 species were recorded, among these 14 common species. Water movement - even at the exposed shore - and sediment quantity of the sheltered site do not seem to affect gammaridean species variety. Species dominance throughout the year varied in exposed and sheltered localities. Hyale media was dominant at the exposed shore, and Amphilochus neapolitanus was the most abundant species at the sheltered shore.
\end{abstract}

\section{INTRODUCTION}

Marine macro-algae are inhabited by a variety of sessile and vagile animals. Among the latter, the Amphipoda frequently comprise the dominant group. Authors such as Truchot (1963), Fenwick (1976), Moore (1978) and Nelson (1979) have dealt with the phytal amphipod fauna. Dommasnes (1968) and Moore (1973) studied the phytal fauna from shores exposed to different wave action. In Brazil, investigations on the phytal fauna were made by Lima (1969), Boffi (1972), Leite (1976), Masunari (1976) and Montouchet (1979). Moreira (1973,a,b), Pereira Leite (1976) and Pires (1977) studied the biology of phytal species. Pereira Leite (1976) analyzed the life cycle of the gammaridean Hyale media. The present investigation is concerned with the qualitative and quantitative analysis of the vagile fauna of Sargassum cymosum, especially Gammaridea, inhabiting two shores with different degrees of exposition to waves.

\section{AREA OF INVESTIGATION}

The material was collected at Ubatuba, northern coast of São Paulo State $\left(23^{\circ} 30^{\prime} \mathrm{S}\right.$ and $\left.45^{\circ} 06^{\prime} \mathrm{W}\right)$, at the rocky parts of Praia Grande and Praia do Lamberto (Fig. 1). The first site is considered an exposed shore (Nonato and Pérès, 1961) where the impact of waves on

\footnotetext{
- Contribution No. 476 of Instituto Oceanográfico, Universidade Sào Paulo, Brazil
}

the rocks is considerable. The second area is located at Enseada do Flamengo, on a sheltered shore, with waves of moderate intensity; the amount of detritus is not large, but during heavy rains the runoff of terrigenous material can be considerable (Boffi, 1972). During the study, the annual average values of dissolved oxygen, salinity and temperature of sea water at Praia Grande were $5.19 \mathrm{ml} \mathrm{1}{ }^{-1}, 34.97 \% \mathrm{~S}$ and $23.66^{\circ} \mathrm{C}$, respectively; they are $5.30 \mathrm{ml} \mathrm{l}^{-1}, 34.05 \% \mathrm{~S}$ and $25.01{ }^{\circ} \mathrm{C}$ at Praia do Lamberto. Monthly data of these parameters are given in Figure 2.

\section{MATERIAL AND METHODS}

Sampling was carried out monthly, during low tide, from July 1974 to June 1975. The algae were picked from the substratum and rapidly placed in a plastic bag In the laboratory the samples were treated as follows: (1) The algae were transferred to an enclosure containing water with a few drops of formaldehyde. (2) They were then carefully shaken, branch by branch, in buckets containing water with a few drops of formaldehyde. (3) The water was passed through a sieve (285 $\mathrm{n}$ เ mesh size) where the animals were retained. (4) The different animal groups were sorted out under an ordinary microscope, counted and then preserved in $70.0 \%$ alcohol.

For some gammaridean genera (Leucothoe, Lysianassa; 1 species of Hyale) identification to species was impossible either because they were present in very small numbers, or were still in their early 


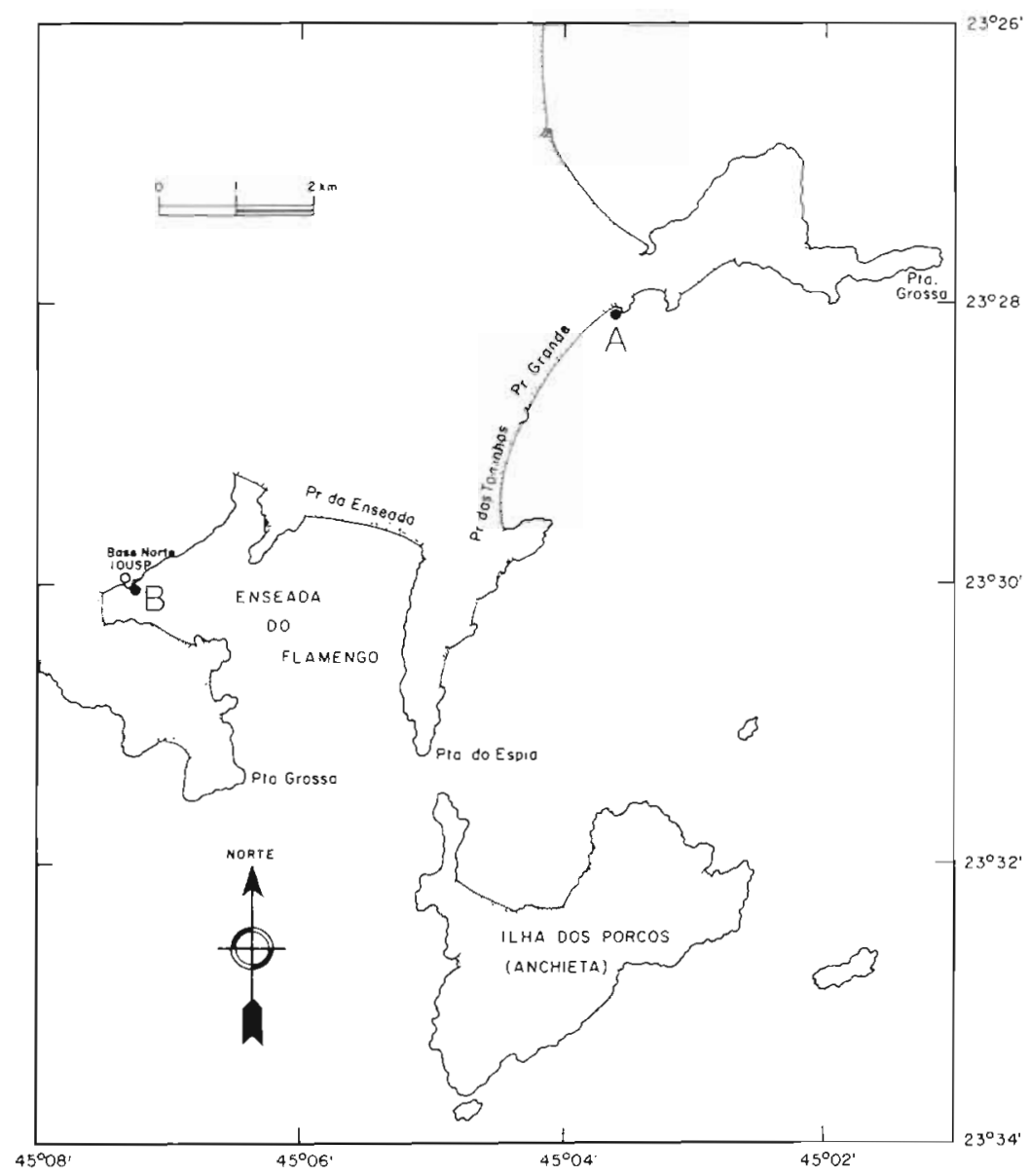

Fig. 1. Sampling stations: Praia Grande (A) and Praia do Lamberto (B)

developmental stages. Quantitative analysis was effectuated by making use of dominance (Da), mean dominance $(\mathrm{mD})$, frequency of occurrence $(\mathrm{Fr})$ and Sorensens's quotient of similarity (Q.S.). Dominance and frequency of occurrence were calculated according to Moore (1971). It was assumed that high dominance occurred when $\mathrm{mD}>40.00 \% ; 40.00 \%>\mathrm{mD}>$ $10.00 \%$ were considered intermediate dominances and $\mathrm{mD}$ values $<10.00 \%$ as low dominances. For Sorensen's quotient of similarity Q.S. $=\frac{2 j}{a+b}$, where $a=$ number of species of Station A (exposed); $b=$ number of species of Station B (sheltered) $; j=$ number of species at both stations (Southwood, 1958).

\section{RESULTS}

\section{Total Fauna}

A total of 122,886 specimens were recorded during 12 months at the two stations. At the exposed site the number of specimens $(59,177)$ represented $48.15 \%$ of the total fauna with 6.94 ind. $\mathrm{g}^{-1}$ Sargassum; at the sheltered site the number of specimens $(63,709)$ represented $51.85 \%$ with 7.34 ind. $g^{-1}$ Sargassum. Foraminifera, Polycladida, Nemertea, Nematoda, Polychaeta, Ostracoda, Copepoda, Tanaidacea, Isopoda, Gammaridea, Caprellidea, Decapoda Natantia, Decapoda Reptantia, Acarina, Pycnogonida, Ophiuroidea, Echinoidea, Crynoidea, Amphineura, Gastropoda Prosobranchia, Gastropoda Opistobranchia, Lamellibranchia and Pisces were found at both shores; Sipunculidea, Mysidacea and Holothuroidea occurred only at the sheltered shore (Table 1). The dominance of Crustacea, Mollusca, Echinodermata, Polychaeta and remaining groups (referred to as other groups') were at the exposed site. Crustacea, $59.24 \%$; Mollusca, 28.65\%; Echinodermata, $0.09 \%$; Polychaeta, $4.64 \%$; other groups', $7.26 \%$; at the sheltered site: Crustacea, $79.98 \%$; Mollusca, $6.81 \%$; Echinodermata, $0.24 \%$; Polychaeta, $3.43 \%$; 'other groups', $9.42 \%$ (Fig. 3). In Figure 3 the predominance of Crustacea is evident; among them the Gammaridea are most conspicuous. Table 1 also lists the annual dominance of each group. 
Table 1. Annual dominance $(\%)$ of groups of organisms col lected at Praia Grande (exposed site) and Praia do Lamberto (sheltered site)

\begin{tabular}{|lcc|}
\hline \multicolumn{1}{|c}{ Organism } & Exposed & Sheltered \\
\hline Foraminifera & 2.73 & 0.32 \\
Polycladida & 0.40 & 0.87 \\
Nemerted & 0.12 & 0.04 \\
Nematoda & 1.18 & 6.70 \\
Sipunculida & - & $\cdot$ \\
Polychaeta & 4.64 & 3.43 \\
Ostracoda & 0.13 & 0.12 \\
Copepoda & 12.32 & 15.36 \\
Mysidacea & - & $\cdot$ \\
Tanaidacea & 0.39 & 0.22 \\
Isopoda & 4.15 & 6.45 \\
Gammaridea & 41.18 & 53.30 \\
Caprellidea & 0.98 & 4.13 \\
Decapoda Natantia & $\cdot$ & 0.36 \\
Decapoda Reptantia & 0.09 & 0.04 \\
Acarina & 2.62 & 1.17 \\
Pycnogonida & 0.21 & 0.32 \\
Ophiuroidea & 0.09 & 0.24 \\
Echinoidea & $\cdot$ & $\cdot$ \\
Holothuroidea & - & $\cdot$ \\
Crinoidea & $\cdot$ & $\cdot$ \\
Amphineura & $\cdot$ & $\cdot$ \\
Gastropoda Prosobranchia & 5.53 & 5.93 \\
Gastropoda Opistobranchia & 0.09 & 0.70 \\
Lamellibranchia & 23.03 & 0.18 \\
Pisces & $\cdot$ & $\cdot$ \\
Groups with Da less than $0.01 \%$ & & \\
& & \\
\hline
\end{tabular}

\section{Gammaridean Fauna}

At the exposed site the monthly contribution of Gammaridea attained a maximum in December 1974 (69.60\%) and a minimum in May 1975 (8.50\%): at the sheltered site the maximum occurred in September 1974 (76.75\%), the minimum in March 1975 (8.43\%) (Fig. 4). Frequency of occurrence (Fr) and mean dominance $(\mathrm{MD})$ of gammaridean species are listed in Table 2. Hyale media had $100.00 \%$ Fr at both sites throughout the period of observation, but with a high mD only at the exposed site. Amphilochus neapolitanus, with $83.33 \%$ Fr at the exposed site and $100.00 \%$ at the sheltered one, revealed at the sheltered site a high $\mathrm{mD}$. Sunamphithoe pelagica with $100.00 \%$ Fr at both shores had an intermediate $\mathrm{mD}$ at the both sites. Stenothoe valida occurred almost throughout the year at both shores with an intermediate $\mathrm{mD}$ at the exposed and with a low $\mathrm{mD}$ at the sheltered site. Ampithoe ramondi, Aora atlantidea, Ericthonius brasiliensis and Tethygeneia longleyi attained $100.00 \%$ Fr at the sheltered site, but had a lower occurrence in the exposed area, with a low $\mathrm{mD}$ at both sites. The Fr of Elasmopus pectinicrus, Gammaropsis atlantica, Hyale sp. and Jassa falcata was, respectively, $91.66 \%, 66.66 \%$,
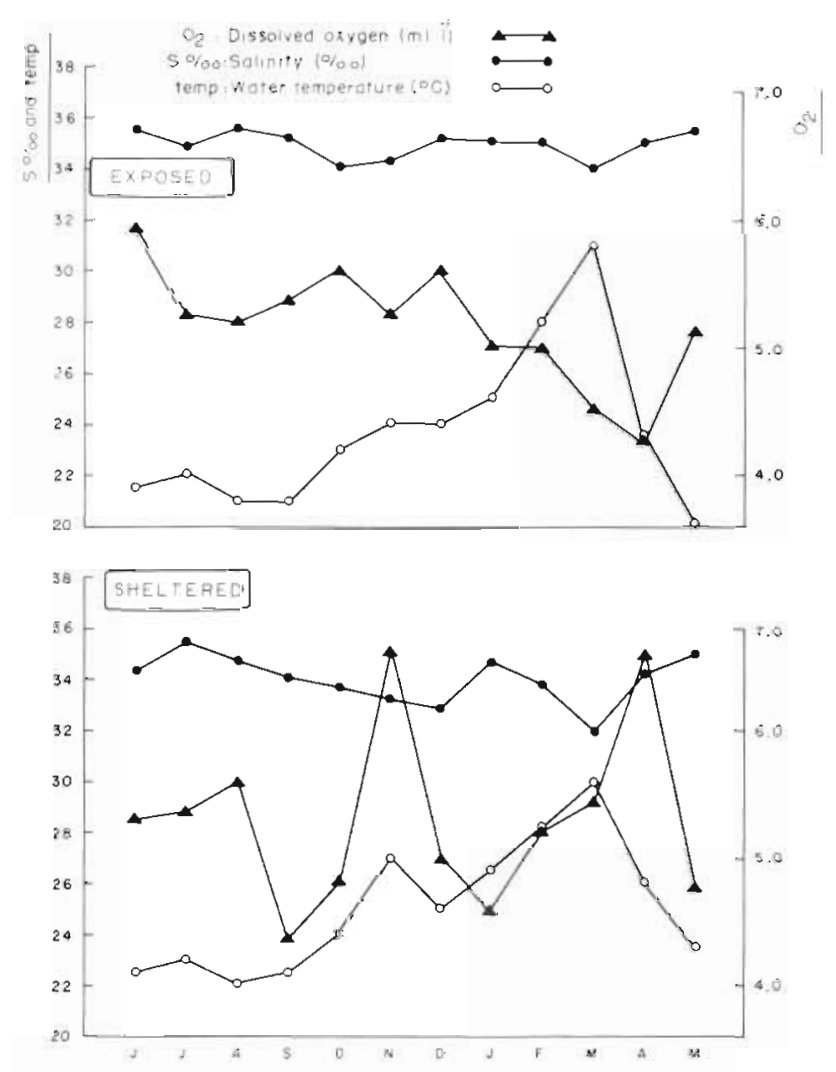

Fig. 2. Variation in physico-chemical parameters at the survey sites
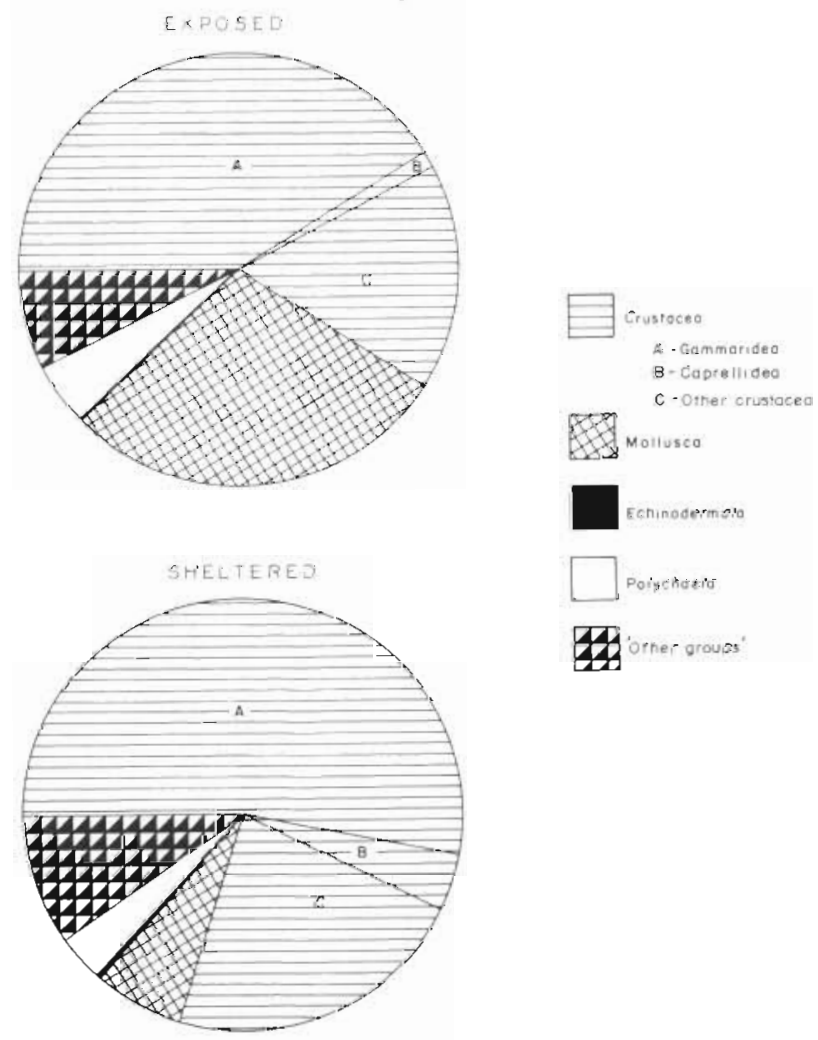

48

Fig. 3. Dominance of Crustacea, Mollusca, Echinodermata, Polychaeta and other groups 


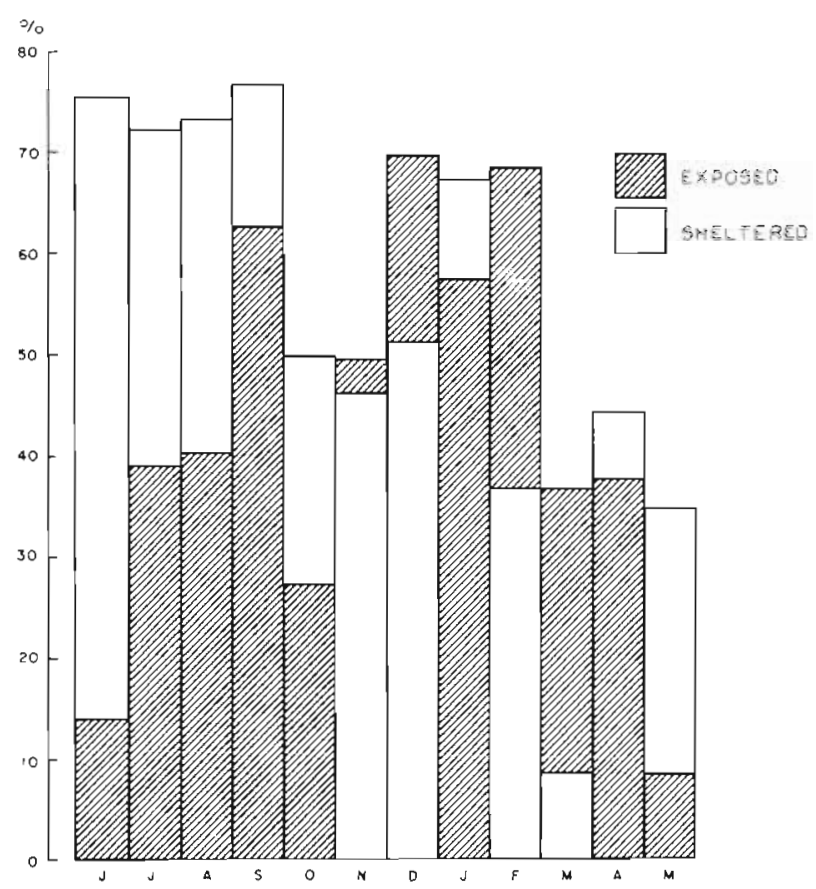

Fig. 4. Gammaridean monthly dominance at both shores

Table 2. Frequency of occurrence (Fr), mean dominance $(\mathrm{mD} ; \%)$ of gammaridean species at exposed and sheltered sites

\begin{tabular}{|lrrrrr|}
\hline & \multicolumn{2}{c}{ mD } & \multicolumn{2}{c|}{ Fr } \\
& Ex- & Shel- & Ex- & Shel- \\
& posed & tered & posed & tered \\
\hline Amphilochus neapolitanus & 10.87 & 47.67 & 83.33 & 100.00 \\
Ampithoe ramondi & 0.37 & 8.29 & 66.66 & 100.00 \\
Cymadusa filosa & 0.08 & 1.47 & 41.66 & 66.66 \\
Sunamphithoe pelagica & 13.32 & 17.02 & 100.00 & 100.00 \\
Atylus minikoi & - & $\cdot$ & - & 8.33 \\
Aora atlantidea & 0.11 & 2.85 & 75.00 & 100.00 \\
Gammaropsis atlantica & 0.17 & - & 66.66 & - \\
Tethygeneia longleyi & 0.26 & 4.60 & 0.16 & 100.00 \\
Elasmopus pectinicrus & 1.73 & $\cdot$ & 91.66 & 16.66 \\
Hyale media & 52.35 & 11.97 & 100.00 & 100.00 \\
Hyale sp. & 1.63 & $\cdot$ & 91.66 & 8.33 \\
Ericthonius brasiliensis & 0.03 & 4.43 & 16.66 & 100.00 \\
Jassa falcata & 0.18 & $\cdot$ & 66.66 & 8.33 \\
Leucothoe sp. & 0.01 & 0.07 & 16.66 & 33.33 \\
Lysianassa sp. & $\cdot$ & 0.07 & 8.33 & 41.66 \\
Stenothoe valida & 18.85 & 1.36 & 83.33 & 91.66 \\
& & & & \\
- (mD) less than $0.01 \%$ & & & & \\
\hline
\end{tabular}

$91.66 \%$ and $66.66 \%$ at the exposed shore; at the sheltered one Elasmopus pectinicrus, Hyale sp. and Jassa falcata had a lower Fr and Gammaropsis atlantica was absent. Cymadusa filosa presented $41.66 \%$ and $66.66 \%$ of $\mathrm{Fr}$ at exposed and sheltered sites, respectively. A low $\mathrm{mD}$ was verified at both sites for these last 5 species. The dominant species at the

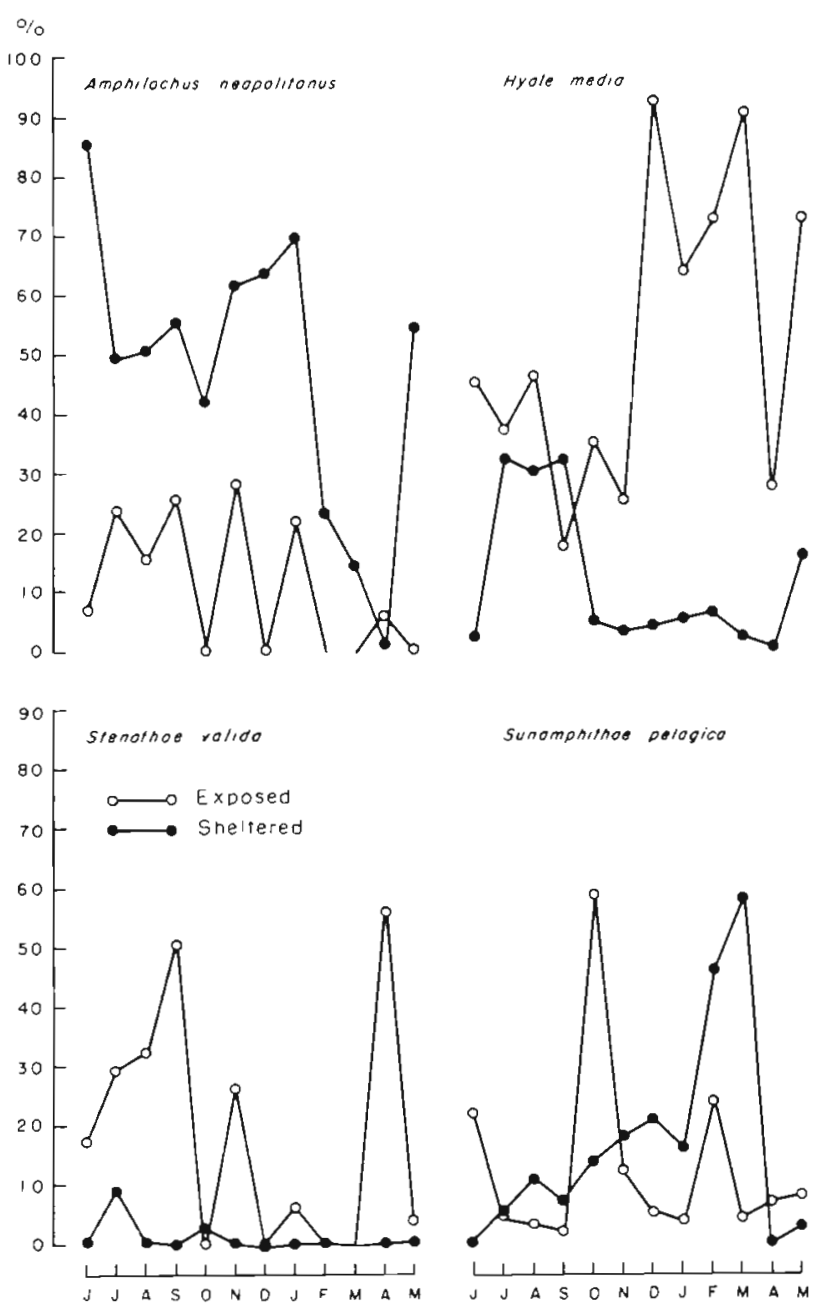

Fig. 5. Variation in monthly dominance of Amphilochus neapolitanus, Hyale media, Stenothoe valida and Sunamphithoe pelagica

sheltered shore was Amphilochus neapolitanus (mD $47.67 \%$ ), followed by Sunamphithoe pelagica $(\mathrm{mD}$ $17.02 \%$ ) and Hyale media (mD $11.97 \%$ ). The other $\mathrm{mD}$ ranged between $8.29 \%$ and less than $0.01 \%$ The exposed shore was dominated by Hyale media $(\mathrm{mD}$ $52.35 \%$ ), followed by Stenothoe valida ( $\mathrm{mD} 18.85 \%$ ) and Sunamphithoe pelagica (mD $13.32 \%$ ). The $\mathrm{mD}$ of the remaining species ranged between $10.87 \%$ and less than $0.01 \%$.

The patterns of monthly fluctuations of one species differ at each shore (Figs 5,6 and 7). At the exposed site Hyale media showed the highest Da in December and March, at the sheltered one in July and September. At the exposed site the Da of Sunamphithoe pelagica was higher in October, at the sheltered one in March. The Da of Stenothoe valida increased in September and April on the exposed shore and decreased on the sheltered one during the whole study period. Amphilochus neapolitanus revealed a minor Da on the 

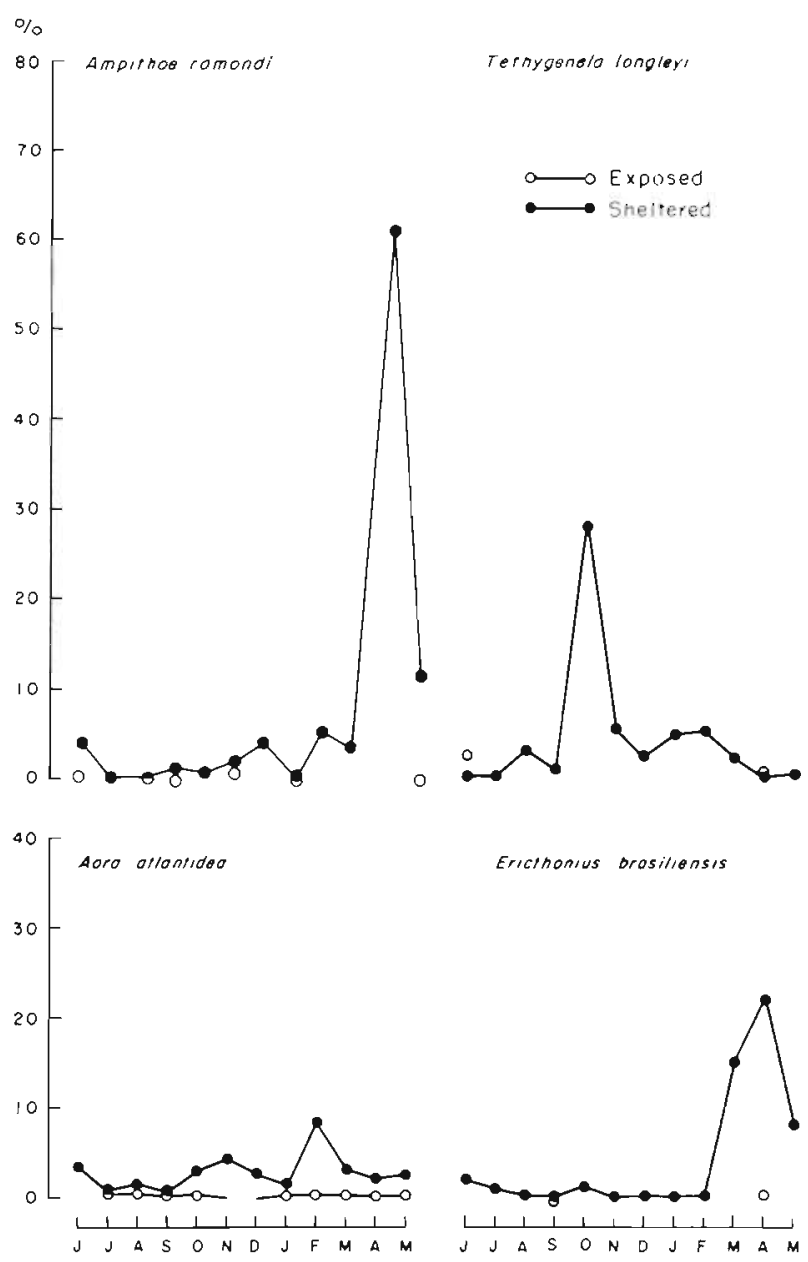

Fig. 6. Variation in monthly dominance of Ampithoe ramondi, Tethygeneia Longleyi, Aora atlantidea and Ericthonius brasiliensis

exposed shore and on the sheltered one a higher Da in June and January. Ampithoe ramondi had a decreased Da at the exposed site and the highest Da in April at the sheltered one. The remaining species showed a Da below $30.00 \%$ throughout the study period. The monthly data of Sorensen's quotient of similarity in Gammaridea were $60.00 \%$ to $70.00 \%$; they are illustrated in Figure 8.

\section{DISCUSSION}

The number of specimens collected on the exposed shore did not differ significantly from that on the sheltered shore. Of the total number of animals collected, $48.15 \%$ (density: 6.94 ind. $\mathrm{g}^{-1}$ Sargassum) were found at the exposed and $51.85 \%$ (7.34 ind. $\mathrm{g}^{-1}$ Sargassum) at the sheltered site.

Sheltered sites usually entertain a greater diversity of species and faunal density than exposed sites
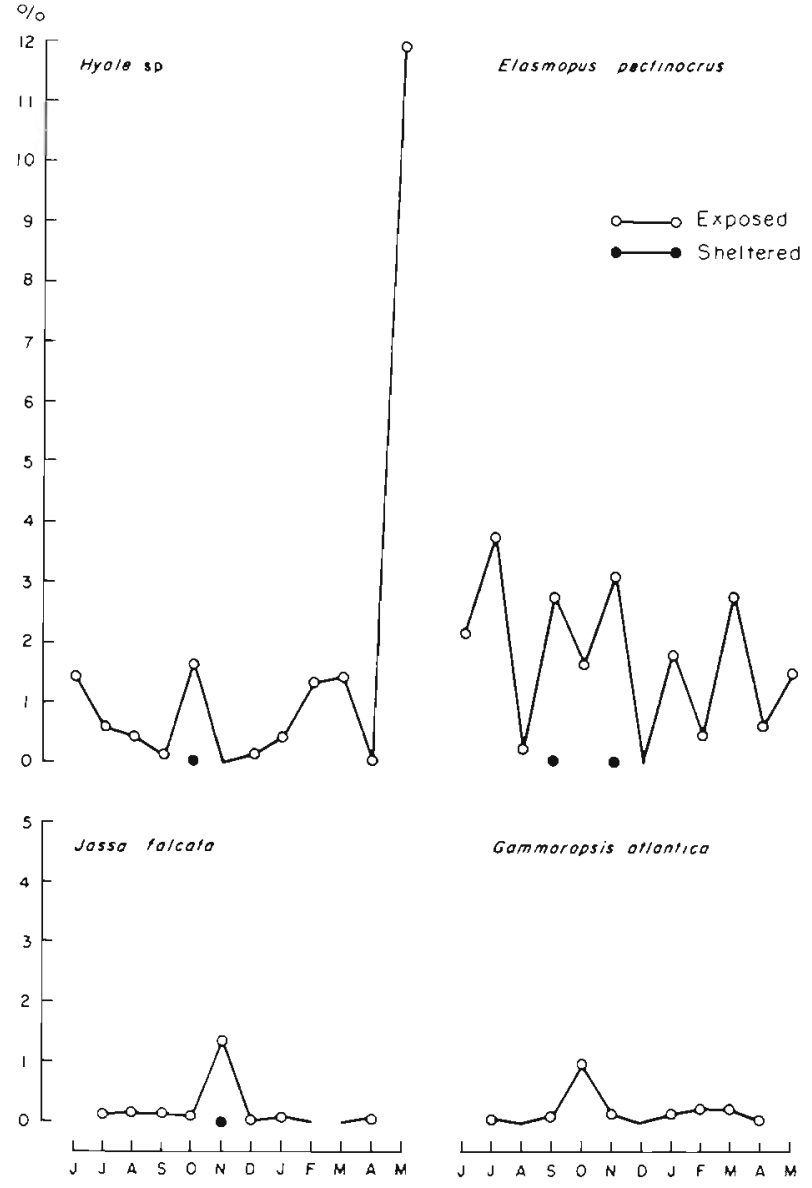

Fig. 7 Variation in monthly dominance of Hyale sp., Elasmopus pectinicrus, Jassa falcata and Gammaropsis atlantica

(Hagerman, 1966; Hällfors et al., 1975). The reasons for the difference in the number of individuals collected on the two shores are difficult to explain. A number of factors may have acted differentially on both shores, such as the rate of sediment deposition on the algae (Hagerman, 1966), and variation in plant biomass (Mukai, 1971; Hällfors et al., 1975). A detailed analysis of the factors lies outside the scope of the present study.

The dominance of Gammaridea over other animals on Sargassum $-41.18 \%$ at the exposed and $53.30 \%$ at sheltered site (Tab. 1) - was conspicuous during the present study on both shores. On several types of algae, Dahl (1948) records Amphipoda and Harpacticoidea as being dominant; for Laminaria hyperboria Moore (1973) also found a dominance of Amphipoda. However, on Fucus serratus, Ostracoda dominate throughout the major part of the year; Lammelibranchia only in summer (Hagerman, 1966); Nematoda in the spring, summer and autumn; Harpacticoidea in winter (Ohm, 1964).

The characteristic species on the exposed shore (Tab. 2) was Hyale media (high $\mathrm{mD}$ and Fr), accom- 


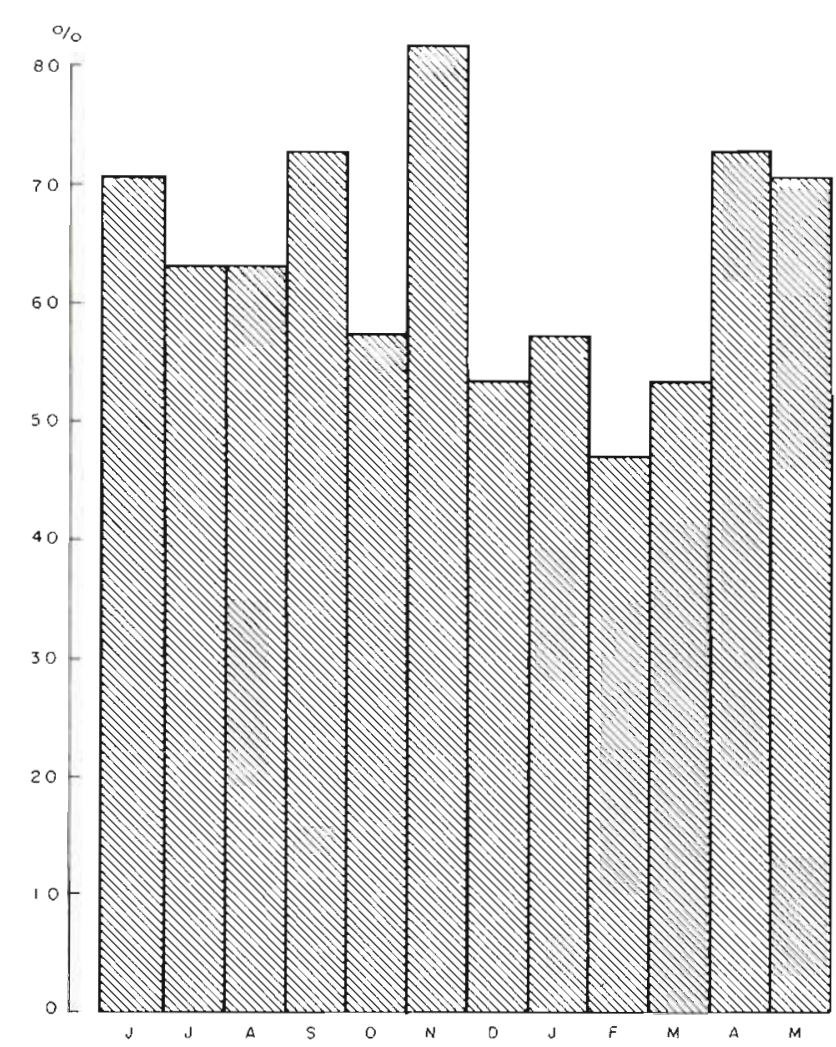

Fig. 8. Annual variation in quotient of similarıty for gammar1dean species on survey shores

panied by Sunamphithoe pelagica, Stenothoe valida, Amphilochus neapolitanus (intermediate $\mathrm{MD}$ and high Fr), Elasmopus pectinicrus, Gammaropsis atlantica, Hyale sp. and Jassa falcata (low $\mathrm{mD}$ and high Fr). On the sheltered shore the most conspicuous species was Amphilochus neapolitanus (high $\mathrm{MD}$ and Fr), followed by Sunamphithoe pelagica and Hyale media (intermediate $\mathrm{mD}$ and high Fr). Finally, Ampithoe ramondi, Aora atlantidea, Ericthonius brasiliensis, Tethygeneia longleyi and Stenothoe valida, although presenting low $\mathrm{mD}$ values, were present - except the last species throughout the study period.

The same number of gammaridean species, 15 in both localities, of which 14 were common species, appear to indicate that these species are well adapted to life under conditions of different wave exposure. Among phytal Gammaridea, some species avoid displacement by inhabiting tubes, others are able to hold on to the algae, or to swim to more secure sites during storm. Tube-dwellers require building material (Moore, 1973); however, even on the sheltered shore. the small quantity of sediment available on the algae may have limited the variety of species. Nevertheless, the $\mathrm{MD}$ values of certain tube-builders - such as Cymadusa filosa, Ericthonius brasiliensis, and Ampithoe ramondi - were higher on the sheltered than on the exposed shore. Therefore, neither water movement nor the amount of sediment seem to affect species variety, but their quantity. Moreover, Sorensen's quotient of similarity, for Gammaridea of the two localities revealed no conspicuous differences.

Different views exist with regard to the number of individuals of Gammaridea, living under different conditions of wave actions. Fenwick (1976) reports a lower density on a sheltered shore; Moore (1978) found no significant differences in amphipod densities; according to Gibson (1972) stomachs of fishes from the sheltered site contained higher percentages of amphipods than those from exposed localities. In our study, the Da of Gammaridea was higher on the sheltered than on the expored shore (Fig. 4), during the greater part of the study period.

Increases in the number of individuals of a given species at a certain time of the year (Figs 5, 6, 7), could bc due to differential reproductive activities of the species involved. Studying the life cycle of Hyale media Pereira Leite (1976) concluded that this species breeds continuously throughout the year, with two periods of intense reproduction. Pires (1977) found continuous reproduction, with peaks twice a year, in Janaira gracilis. According to Thorson (1950), tropical species are noted for such pattern of reproduction.

\section{LITERATURE CITED}

Boffi, E. (1972). Ecological aspects of ophiuroids from the phytal of S. W. Atlantic Ocean warm waters. Mar Bial 15: 316-328

Dahl, E. (1948). On the smaller Arthropoda of marme algae, specially in the polyhaline waters off the Swedish west coast. Dissertation, Lund. Unders, over Oresund 35: 1-193

Dommasnes, A. (1968). Variation in the meiofauna of CoralIna officunalis L. with wave exposure. Sarsia 34: 117-124

Fenwick, G. D. (1976). The effect of wave exposure on the amphipod fauna of the alga Caulerpa brownit. J. exp. mar. Biol. Ecol. 25: 1-18

Gibson, R. N. (1972). The vertical distribution and feeding relationships of intertidal fish on the Atlantic cuast of France. J. Anim. Ecol. 41: 189-201

Hälfors, G., Kangas, P., Lappalainen, A. (1975). Lulloral Benthos of the Northern Baltic sea. III. Macrobenthos of the hydrolittoral belt of filamentous algae on rocky shores in Tavarminne. Int. Revue ges. Hydrobiol. 60: 313-333

Hagerman, L. (1966). The macro and microlaund associated with Fucus serratus L., with some ecological remarks. Ophelia 3: 1-43

Moreira, P. S. (1973a). Behavioral aspects of Arcturehla sawayae Moreira, 1973 (Crustacea, Isopoda, Valvifera). Bolm Zool. Biol. Mar, n.s. (30): 195-216

Moreira, P. S. (1973b). Food and feeding behavior of Arctureila sawayae Moreita, 1973 (Crustacea. Isopoda, Valviferaj. Bolm Zool. Biol. Mar. n.s. (30): 217-232

Mukai, H. (1971). The phytal animals on the thalli of Sargassum serratifolium in the Sargassum region, with reference to their seasonal fluctuations. Mar. Biol. 8: 170-182 
Nelson, W. G. (1979). An analysis of structural pattern in an eelgrass (Zostera marina L.) amphipod community. J. exp. mar. Biol. Ecol. 39: 231-264

Nonato, E. F., Pérès, J. M. (1961). Observatıons sur quelques peuplements intertidaux substrat dur dans la régron d Ubatuba (Etat de Sào Pauio). Cah. Biol. mar 2 (3): $263-270$

Ohm, G. (1964). Die Besiedlung der Fucus-zone der Kieler Bucht und der westlichen Ostsee unter besonderer Berucksichtıgung der Mikrofauna. Kieler Meerestorsch. 20: $30-64$

Pereira Leite, F. P. (1976). Estadıos de crescimento e aspectos da reprodução de Hyale media (Crustacea, Amphipoda, Hyalidae) da fauna vágil de Sargassum cymosum. M. Sc. thesis, Instituto Oceanográfico da Universidade de São Paulo, Brasi]

Leite, Y M. R. (1976). Aspectos ecológicos do fital da Halimeda opuntia (Linnaeus) Lamouroux. M. Sc thesis, Instituto de Biociências da Universidade de São Paulo, Brasil

Lima, H. S. (1969). Fauna séssil do Sargassum cymosum da Praia do Lamberto, Ubatuba (Estado de São Paulor: composição qualitativa e consideraçōes sobre a localização das espécies na planta. M. Sc. thesis, Instituto Oceanográfico da Universidade de São Paulo, Brasil

Masunari, S. (1976). O fital de Amphiroa fragilissima (Lin- naeus) Lamouroux, 1816 da Praia do Lazaro, Ubatuba, São Pauio. M. Sc. thesis, Instituto de Blociências da Universidade de Sào Paulo, Brasil

Montouchet, P. E. G. (1979). Sur la communauté des anımaux vagiles associés à Sargassum cymosum C. Agardh, à Ubatuba, Etat de Sāo Paulo, Brésil. Stud. neotrop. Faund Enviromm. 14: 33-64

Moore, P. G. (1971). The nematode fauna associated with holdfast of kelp (Laminaria hyperborea) in North-East Britain. J. mar. biol. Ass. U.K. 51. 589-604

Moore, P. G. (1973). The larger Crustacea associated with holdfasts of kelp (Laminaria hyperborea) in North-East Britain. Cah. Biol. mar. 14 (4): 493-518

Moore, P. G. (1978). Turbidity and kelp holdfast Amphipoda. I. Wales and S.W. England. J. exp. Mar. Biol. Ecol. 32 (1): $53-96$

Pires, A. M. S. (1977). Ciclo reprodutivo e flutuaçāo anual da populaçào de Janaira gracilis (Crustacea, Isopoda, Asellota). Bolm Inst. oceanogr S. Paulo 26: 201-217

Southwood, T R. E. (1958). Ecological methods, Methuen, London

Thorson, G. (1950). Reproductive and larvae ecology of marine bottom invertebrates. Biol. Rev. 25 (1): 1-45

Truchot, J. P. (1963). Etude faunistique et ecologique des Amphipodes des faunes rocheaux intertidaux de Roscoff. Cah. Biol. mar 4:121-176 